\title{
IMPACT OF MICROFINANCE ON THE SOCIAL DEVELOPMENT OF BENEFICIARIES OF SYANGJA DISTRICT, NEPAL
}

\author{
Chandra Prasad Dhakal *
}

\begin{abstract}
Microfinance is known as economic crisis manager of rural society. It provides the easy loan along with the skill of financial management and other orientation program. Microfinance is the friend of poor who always become ready to support the poor, marginalized and disadvantage communities. The study aims to identify the social impact of microfinance on the beneficiaries of Syangja district. The data collected were from the 385 beneficiaries of microfinance through structured questionnaire. The study has measured the impact of microfinance on education, healthcare, decision making power and women's empowerment. There was significant impact observed on the social development of beneficiaries. This study had compared the changes between poor and non-poor as the national standard of poverty. There was significant association between poor and non-poor in the most of cases which had indicated significantly different effect of facilities provided by the microfinance.
\end{abstract}

Key words: Education, health, microfinance, social

\section{INTRODUCTION}

The word microfinance is new term used in the history of rural microfinance. In the context of Nepal, microfinance has been used after 1990s. Although rustic credit in Nepal began in 1956 with the opening of credit cooperatives in Chitwan Valley to provide loans to the re-settlers coming from different parts of the country (Kabeer, 2003). The main focus of microfinance service is the saving and credit facilities, being provided to the poor, disadvantage, marginalized and women of rural society. Economic status is the base of other social development of individual.

Microfinance has a very important role to play in development according to its scope. Many studies have shown that microfinance plays three key roles: It helps very poor households to meet basic needs and

\footnotetext{
* Mr. Dhakal is Lecturer in Economics, Saraswati Campus, Lekhnath Marg, TU.
} 
108 IMPACT OF MICROFINANCE ON THE SOCIAL DEVELOPMENT OF ...

protects against risks. It is associated with improvements in household economic welfare and it also helps to empower women by supporting women's economic participation and so promotes gender equity. While analyzing the impact of microfinance, social impact must be assessed. Kabeer (2003) states that wider social impact assessment is important for an organization's internal learning process, as an microfinance institutions should be aware of the 'full range of changes associated with its efforts and uses these to improve its performance'. She considers social impact to relate to human capital such as nutrition, health and education, as well as social networks.

Zohir and Matin (2004) make a similar point when they state that the impact of microfinance interventions is being under-estimated by 'conventional impact studies which do not take into account the possible positive externalities on spheres beyond households'. They propose that impact should be examined from cultural, economic, social and political domains at individual, enterprise and household levels. Robinson (2001) in a study of 16 different MFIs from all over the world shows that having access to microfinance services has led to an enhancement in the quality of life of clients, an increase in their self-confidence, and has helped them to diversify their livelihood security strategies and thereby increase their income.

Emphasis on women in microfinance was initially based on practical contemplations of ensuring that loans were paid back rather than for any other reason. The Grameen Bank of Bangladesh is the pioneer microfinance institution to experiment with women. Recounting their experience with women. Armendariz \& Morduch, (2005) state Grameen initially did not have such a strong prominence on women when it begun business in the 1970s. Grameen shifted their focus onto women in the early 1980s when they showed better loan repayment histories than men did. The initial idea was to have an equal number of men and women but women's record showed so remarkable a repayment rate that by the end of 2002, 95 percent of Grameen clients were women. Most microfinance institutions have since emulated the practice of targeting women. Cheston \& Kuhn, (2002), recapitulate the rationale for targeting women as certifying efficiency and sustainability of microfinance institutions: microfinance patterns run efficiently due to women's cooperation and good compensation records. "Their lower arrears and loan loss rates have an important effect 
on the proficiency and sustainability of the institution" (p. 9). Women are more likely than men to self-select into microfinance institutions with some surroundings committed: namely training sessions, small loans, rag meetings and joint obligation (Armendariz de Aghion \& Morduch, 2005). Johnson (1997) also confirm the forgoing argument that women are usually targeted to ensure better loan repayment rates and efficiency in implementation of microfinance services rather than for any other concerns. A study in Nepal to assess the empowerment effect of microfinance interventions by Ashe and Parrot (2001) found that 68 percent of women had experienced an increase in most areas of decision-making traditionally dominated by men. The previous study has clearly shown the contribution of microfinance in the social development from the various perspectives. Basically more contribution can be seen in the economic development but it is also simultaneously contributing in social development. The study aims to identify the social impact of microfinance in particular context of Syangja district of Nepal.

\section{METHODOLOGY}

The study is based on the descriptive design which discusses about the social phenomenon created by impact of microfinance. The study was conducted in the Syangja district of western region which has experienced the long history of microfinance. The data and information were gathered from the 385 direct beneficiaries of microfinance through the structured questionnaire survey. Simple random sampling was used to select the respondent. The total list of beneficiaries was taken from the selected microfinance and did the random sampling. The respondents were pre-informed and taken the written consent before interview. The collected data were analyzed from the statistical software and presented the data in tabular form. The cross-tabulation, mean and Chi-square test were used to analyze the data.

\section{RESULT AND DISCUSSION}

This study has explored the social impact of microfinance services in the study area. Mostly, it assesses on impact of microfinance services on education, health and empowerment of beneficiaries. Okibo and Makanga(2014) illustrates the various ways in which 'microfinance, at its core combats poverty'. They state that microfinance creates access to productive capital for the poor, which together with human capital, 
110 IMPACT OF MICROFINANCE ON THE SOCIAL DEVELOPMENT OF ...

addressed through education and training, and social capital, achieved through local organization building, enables people to move out of poverty. By providing material capital to a poor person, their sense of dignity is strengthened and this can help to empower the person to participate in the economy and society.

\section{Access to education in the family after joining microfinance programs}

The access to education in the family after going microfinance programs was found to be as following:

Table 1: Access to Education in the Family After Joining Microfinance Programs

\begin{tabular}{|c|c|c|c|c|c|c|c|c|c|}
\hline & \multicolumn{5}{|c|}{$\begin{array}{l}\text { Access to Education in the Family } \\
\text { After Joining Microfinance Programs }\end{array}$} & \multirow[b]{2}{*}{ Total } & \multirow[b]{2}{*}{ Mean } \\
\hline & & & 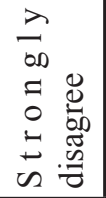 & 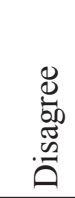 & 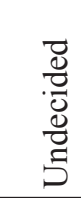 & 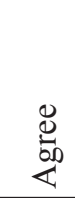 & 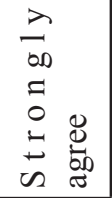 & & \\
\hline \multirow{4}{*}{$\begin{array}{l}\text { National } \\
\text { standard } \\
\text { of poverty }\end{array}$} & \multirow{2}{*}{ Poor } & Count & 2 & 41 & 19 & 64 & 14 & 140 & \multirow{2}{*}{3.3357} \\
\hline & & $\%$ & 1.4 & 29.3 & 13.6 & 45.7 & 10.0 & 100.0 & \\
\hline & \multirow{2}{*}{$\begin{array}{l}\text { Non } \\
\text { poor }\end{array}$} & Count & 2 & 39 & 23 & 150 & 31 & 245 & \multirow{2}{*}{3.6898} \\
\hline & & $\%$ & 0.8 & 15.9 & 9.4 & 61.2 & 12.7 & 100.0 & \\
\hline \multirow{2}{*}{\multicolumn{2}{|c|}{ Total }} & Count & 4 & 80 & 42 & 214 & 45 & 385 & \multirow{2}{*}{3.5610} \\
\hline & & $\%$ & 1.0 & 20.8 & 10.9 & 55.6 & 11.7 & 100.0 & \\
\hline \multicolumn{10}{|c|}{ Chi-Square Tests } \\
\hline & & & \multicolumn{2}{|l|}{ Value } & \multicolumn{2}{|l|}{ Df } & \multicolumn{3}{|c|}{ Asymp. Sig. (2-sided) } \\
\hline \multicolumn{3}{|c|}{ Pearson Chi-Square } & \multicolumn{2}{|l|}{13.804} & \multicolumn{2}{|l|}{4} & \multicolumn{3}{|l|}{.008} \\
\hline
\end{tabular}

Source: Field survey, 2016.

Nepal government has launched many programs to promote the education with slogan of 'Education for all'. The education program is supported by many non-governmental organizations too. The promotion of education is key to development. So, parents are also conscious about the importance of education for their children. The respondents were asked to opine on education access and it was scored in five points Likert Scale. Out of 385 respondents, 4(1\%) strongly disagreed, 80(20.8\%) disagreed, $42(10.9 \%)$ were undecided, 214(55.6\%) agreed and 45(11.7\%) strongly agreed with total mean value is 3.5610 . In comparison of poor and nonpoor, the mean value of poor is 3.3357 whereas mean value of non-poor is 3.6898. The statistical analysis of Pearson Chi-Square test shows that 
there is significant association between poor and non-poor regarding the increased access on education after joining microfinance programs because the $\mathrm{P}=.008$ which is less than .05 significant level (Table 1 ).

Microfinance interventions have also been shown to have a positive impact on the education of clients' children. Littlefield, Murduch and Hashemi (2003, p.4) state that one of the first things that poor people do with new income from micro enterprise activities is to invest in their children's education. Studies show that children of microfinance clients are more likely to go to school and stay longer in school than for children of nonclients. Again, in their study of FOCCAS, client households were found to be investing more in education than non-client households. Similar findings were seen for projects in Zimbabwe, India, Honduras and Bangladesh.

\section{Access to healthcare after joining microfinance programs}

The access on health care after joing microfinance program was found to be as follows:

Table 2: Access to Healthcare After Joining Microfinance Programs

\begin{tabular}{|c|c|c|c|c|c|c|c|c|c|}
\hline & \multicolumn{5}{|c|}{$\begin{array}{l}\text { Access to Healthcare After Joining } \\
\text { Microfinance Programs }\end{array}$} & \multirow[b]{2}{*}{ Total } & \multirow[b]{2}{*}{ Mean } \\
\hline & & & 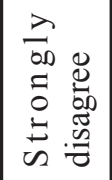 &  & $\begin{array}{l}\frac{\pi}{0} \\
\frac{\pi}{0} \\
\frac{\pi}{0} \\
5\end{array}$ &  & 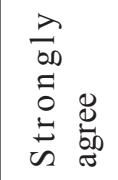 & & \\
\hline \multirow{4}{*}{$\begin{array}{l}\text { National } \\
\text { standard } \\
\text { of } \\
\text { poverty }\end{array}$} & \multirow{2}{*}{ Poor } & Count & 3 & 38 & 23 & 64 & 12 & 140 & \multirow{2}{*}{3.3143} \\
\hline & & $\%$ & 2.1 & 27.1 & 16.4 & 45.7 & 8.6 & 100.0 & \\
\hline & \multirow{2}{*}{$\begin{array}{l}\text { Non } \\
\text { poor }\end{array}$} & Count & 2 & 38 & 51 & 138 & 16 & 245 & \multirow{2}{*}{3.5224} \\
\hline & & $\%$ & 0.8 & 15.5 & 20.8 & 56.3 & 6.5 & 100.0 & \\
\hline \multirow{2}{*}{\multicolumn{2}{|c|}{ Total }} & Count & 5 & 76 & 74 & 202 & 28 & 385 & \multirow{2}{*}{3.4468} \\
\hline & & $\%$ & 1.3 & 19.7 & 19.2 & 52.5 & 7.3 & 100.0 & \\
\hline \multicolumn{10}{|c|}{ Chi-Square Tests } \\
\hline & & & \multicolumn{2}{|l|}{ Value } & \multicolumn{2}{|l|}{ Df } & \multicolumn{3}{|c|}{ Asymp. Sig. (2-sided) } \\
\hline \multicolumn{3}{|c|}{ Pearson Chi-Square } & \multicolumn{2}{|l|}{10.629} & \multicolumn{2}{|l|}{4} & \multicolumn{3}{|l|}{.031} \\
\hline
\end{tabular}

Source: Field survey, 2016.

Nepal is geographically divided into 3 layers: high hill, mountain and plain area. So, infrastructure development and service facilities are 


\section{IMPACT OF MICROFINANCE ON THE SOCIAL DEVELOPMENT OF ...}

different. There is problem of road, electricity, communication in the hilly areas in comparison of plain area.

The respondents were asked to opine on better health access and it was scored in five points Likert Scale. Out of 385 respondents, $451.3 \%$ ) strongly disagreed, 76(19.7\%) disagreed, 74(19.2\%) were undecided, $202(52.5 \%)$ agreed and $28(7.3 \%)$ strongly agreed with total mean value is 3.4468. In comparison of poor and non-poor, the mean value of poor is 3.3143 whereas mean value of non-poor is 3.5224 . The statistical analysis of Pearson Chi-Square test shows that there is significant association between poor and non-poor regarding the increased access on health after joining microfinance programs because the $\mathrm{P}=.031$ which is less than .05 significant level (Table 2).

Health is a fundamental human right. The mandate of The Constitution of Nepal 2070 (2014) emphasized that every citizen shall have the right to basic health-care services free of cost, as provided by law (Nepal Government, 2007). As a result, the Government of Nepal has provided essential healthcare services free of charge in district hospitals, primary healthcare centers, health posts and sub health posts, to all people (Department of Health Services, 2007). The free health-care policy covers consultation and treatment, minor surgery, obstetric emergencies, basic and comprehensive obstetric care, radiographs, laboratory services, essential drugs (for a week) and transport by ambulance to a higher-level facility when a patient is referred (Ministry of Health and Population, 2006). Because of this free health-care initiative, health-care access is steadily expanding; however, critical gaps still persist, and additional resources for health are required (WHO, 2011). Health seeking behavior is affected by the access, awareness and economic status. Microfinance services supported to improve the economic status of individual, which can improve the capacity to afford the health expenditure.

Health and education are two key areas of non-financial impact of microfinance at a household level. Wright (2000)states that from the little research that has been conducted on the impact of microfinance interventions on health and education, nutritional indicators seem to improve where MFIs have been working. Research on the Grameen Bank shows that members are statistically more likely to use contraceptives than non-members thereby 
impacting on family size. Littlefield, Murduch and Hashemi (2003) also acknowledge the sparse specific evidence of the impact of microfinance on health but where studies have been conducted they conclude, "households of microfinance clients appear to have better nutrition, health practices and health education than comparable non-client households" (p. 3). Among the examples they give is of FOCCAS, a Ugandan MFI whose clients were given health care instructions on breastfeeding and family planning. They were seen to have much better health care practices than non-clients, with 95 percent of clients engaged in improved health and nutrition practices for their children, as opposed to 72 percent for non-clients.

\section{Role in decision making after joining microfinance programs}

Table 3: Role in Decision Making After Joining Microfinance Programs

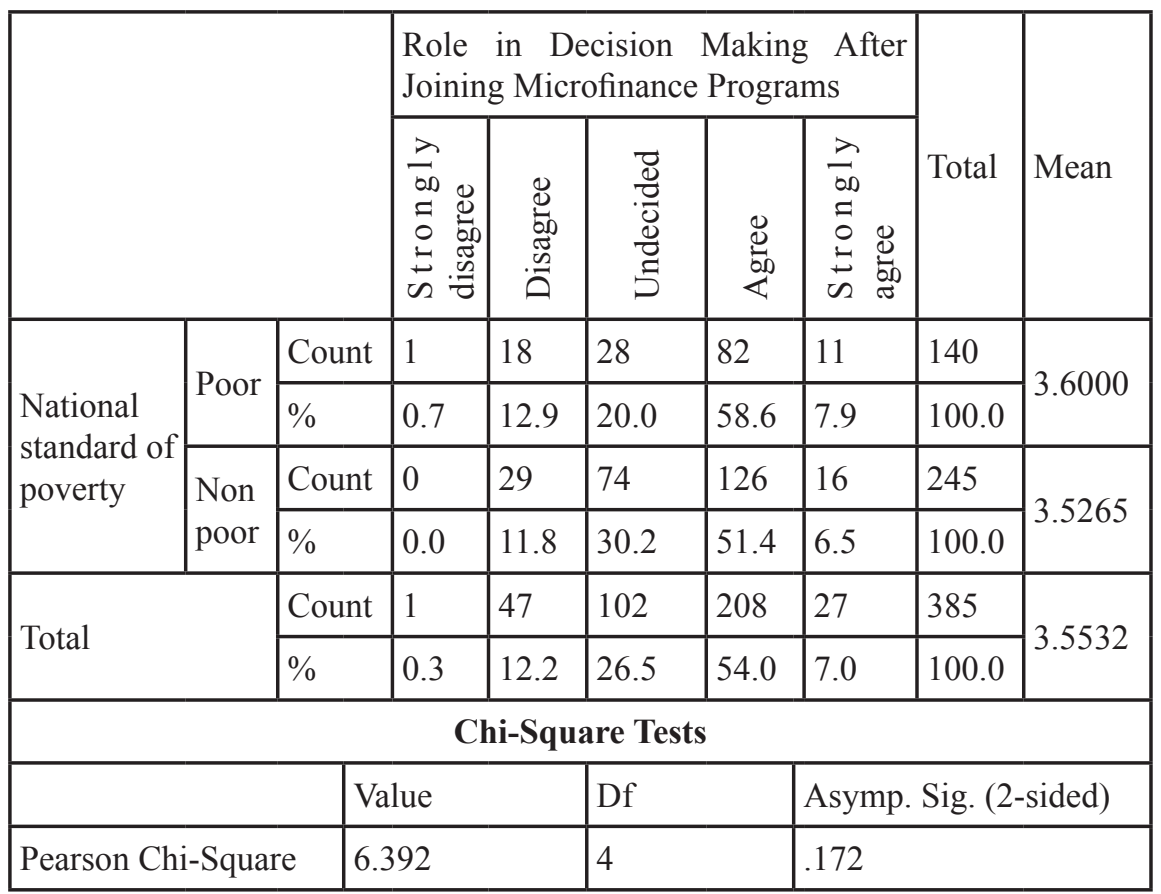

Source: Field survey, 2016.

In the questionnaire, there was one question about decision-making role after joining microfinance programs. Out of 385 respondents, $1(0.3 \%)$ strongly disagreed, 47(12.2\%) disagreed, 102(26.5\%) were undecided, $208(54 \%)$ agreed and $27(7 \%)$ strongly agreed on it with total mean value 


\section{IMPACT OF MICROFINANCE ON THE SOCIAL DEVELOPMENT OF ...}

3.5532. In comparison of poor and non-poor, the mean value of poor is 3.6000 whereas mean value of non-poor is 3.5265 . The statistical analysis of Chi-Square test shows that there is no significant association between poor and non-poor regarding increase of role in decision making after joining the microfinance program because the $\mathrm{P}=.172$ which is greater than .05 significant level (Table 3).

It has satisfactory result. When a person gets opportunity of income generation that obviously leads him/her to decision-making. Decision making capacity depends on the knowledge of particular issue or event and skill of handling the issue and mass mobilization skill. Decision making skill leads the leadership skill. In Nepalese society, income influences more on decision-making; who have more income in family s/he becomes stronger in family decision.

Interaction with Mrs. Dhanamaya Darji of Kolma, Syagja, she was in her tailoring business, got tailoring training from microfinance service and they also gave her loan for tailoring. She got NPR.25000 to purchase the tailoring machines. So she purchased one machine and started working. Within one year, she returned the loan and became independent self-employee. Gradually, she purchased total 5 machines and 4 people are currently working in her tailors. She was providing training to the interested people also. Till this date, she has trained more than 25 local women. Among them, many have started their business in other part of Syangja district; some have gone in Kathmandu, Pokhara for business purpose. She is earning monthly 20 to 25 thousand Nepalese rupees that is enough to manage the household expenditure. Her two children are studying in private school. She is doing her own business and supporting her family, so her husband and other family members are happy with her. Her family members are supporting in her business. Her husband has given all authority of household decision to her. So, she feels proud to be a responsible person of family and society. She is involved in different social activities. She never feels any type of social discrimination from society being women or member of disadvantaged group.'

Littlefield, Murduch and Hashemi (2003) state that access to MFIs can empower women to become more confident, more assertive, more 
likely to take part in family and community decisions and better able to confront gender inequities.

Following a three-year study of 906 clients, microfinance institutes working with 60,000 rural women in Tamil Nadu, India, found that their project had many positive impacts on their clients (Noponen, 2005). The programme was having a "positive impact on livelihoods, social status, treatment in the home and community, living conditions and consumption standards'. Compared with new members, some of the findings showed that long-term members were more likely to live in tile roofed and concrete houses, to have a higher percentage of their children in school, to have lower incidence of child labour, to be the largest income provider or joint provider in the home, and to make decisions on their own as regards major purchases.

\section{Women awareness about their rights}

Table 4: Women Awareness about Their Rights



Source: Field survey, 2016. 


\section{IMPACT OF MICROFINANCE ON THE SOCIAL DEVELOPMENT OF ...}

The study measured the contribution of microfinance in women empowerment from the social empowerment perspective. Before measuring the empowerment, the question raised in mind that 'What is empowerment'? There are several interpretations. Krishna (2003) defines empowerment as the process of increasing the capacity of individuals or groups to make choices and to transform those choices into desired actions and outcomes. The World Bank also identifies four key elements of empowerment to draft institutional reforms: access to information; inclusion and participation; accountability; and local organizational capacity (World Bank, 2001). There was one question within the survey questionnaire whether microfinance programs have empowered women to speak about their rights and about household assets. Out of 385 respondents, 6 (1.6\%) strongly disagreed, $67(17.4 \%)$ disagreed, 74(19.2\%) were undecided, 206(53.5\%) agreed and $32(8.3 \%)$ strongly agreed on it with mean value is 3.4961. It is satisfactory result. In comparison of poor and non-poor, the mean value of poor is 3.6071 whereas mean value of non-poor is 3.4327 . The statistical analysis of Chi-Square test shows that there is no significant association between poor and non-poor regarding the role of microfinance programs to empower the women about their rights of property because the $\mathrm{P}=.055$ which is greater than .05 significant level.

From the discussion with microfinance and its beneficiaries, it is found that majority of microfinance program target women with the explicit goal of empowering them. Empowerment of women is defined as the process in which women challenge the existing socio-cultural norms and values, rules and regulation, gender relationship to effectively improve their well-being. 


\section{Empowerment of women to sell or purchase the assets}

Table 5: Empowerment of Women to sell or purchase the Assets

\begin{tabular}{|c|c|c|c|c|c|c|c|c|c|}
\hline & \multicolumn{5}{|c|}{$\begin{array}{l}\text { Empowerment of Women to sell or } \\
\text { purchase the Assets }\end{array}$} & \multirow[b]{2}{*}{ Total } & \multirow[b]{2}{*}{ Mean } \\
\hline & & & 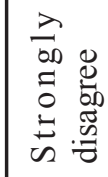 & 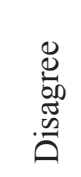 & 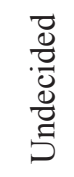 & $\underset{0}{0}$ & 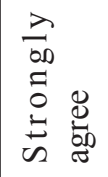 & & \\
\hline \multirow{4}{*}{$\begin{array}{l}\text { National } \\
\text { standard of } \\
\text { poverty }\end{array}$} & \multirow{2}{*}{ Poor } & Count & 30 & 68 & 11 & 16 & 15 & 140 & \multirow{2}{*}{2.4143} \\
\hline & & $\%$ & 21.4 & 48.6 & 7.9 & 11.4 & 10.7 & 100.0 & \\
\hline & \multirow{2}{*}{$\begin{array}{l}\text { Non } \\
\text { poor }\end{array}$} & Count & 35 & 108 & 46 & 46 & 10 & 245 & \multirow{2}{*}{2.5429} \\
\hline & & $\%$ & 14.3 & 44.1 & 18.8 & 18.8 & 4.1 & 100.0 & \\
\hline \multirow{2}{*}{\multicolumn{2}{|c|}{ Total }} & Count & 65 & 176 & 57 & 62 & 25 & 385 & \multirow{2}{*}{2.4961} \\
\hline & & $\%$ & 16.9 & 45.7 & 14.8 & 16.1 & 6.5 & 100.0 & \\
\hline \multicolumn{10}{|c|}{ Chi-Square Tests } \\
\hline & & & \multicolumn{2}{|l|}{ Value } & \multicolumn{2}{|l|}{$\mathrm{Df}$} & \multicolumn{3}{|c|}{ Asymp. Sig. (2-sided) } \\
\hline \multicolumn{3}{|c|}{ Pearson Chi-Square } & \multicolumn{2}{|l|}{19.281} & \multicolumn{2}{|l|}{4} & \multicolumn{3}{|l|}{.001} \\
\hline
\end{tabular}

Source: Field survey, 2016.

Respondents were asked on whether microfinance programs have empowered women to sell or purchase land independently. Out of 385 respondents, 65(16.9\%) strongly disagreed, 176(45.7\%) disagreed, $57(14.8 \%)$ were undecided, 62(16.1\%) agreed and 25(6.5\%) strongly agreed on it with mean value is 2.4961 . In comparison of poor and nonpoor, the mean value of poor is 2.4143 whereas mean value of non-poor is 2.5429. The statistical analysis of Pearson Chi-Square test shows that there is significant association between poor and non-poor regarding role of microfinance programs to empower the women because the $\mathrm{P}=.001$ which is less than .05 significant level (Table 5).

The result shows that microfinance programs alone cannot empower women on all the sectors. Still other political and cultural obstacles do not allow women to come front on such case.

The study collected opinions of respondents to know the contribution of microfinance in women empowerment. Mrs. Sanumaya B.K. from Putlibazaar, Syagja shared her experience about the empowerment of 


\section{IMPACT OF MICROFINANCE ON THE SOCIAL DEVELOPMENT OF ...}

women through the activities of microfinance program that she was doing off seasonal vegetable farming after getting the training from microfinance. She said that she got the skill as well as loan to start farming from microfinance. She took NPR. 50000/- from microfinance and started farming five years back prior date of this interview. Initially, she had no own land for farming so took land in rent. She took 1 hectare of land for rent in the beginning. Gradually, she increased the land size and now she has been doing farming in 6.5 hectares where 2 hectares of land is her own. She purchased it from the profit of vegetable farming. Annually, she has been earning 2-3 lakh net profit from the farming. So, now she has been able to manage her house well. She felt the significant change in her life after involving in microfinance activities. She has been involved in different social groups too. She can communicate well; can speak on the rights of women in front of mass. So, there has been change in her social life too.

\section{CONCLUSION}

Microfinance is significantly contributing in the rural areas of Nepal, basically women; disadvantaged and marginalized communities are more targeted and benefited. Saving and credit activity is more visible program of microfinance but indirectly it has contributed in the social development of people, like increased the livelihood, increased access on education, better access in health care and developed the social networking. It is the common nature of all community that access and power increased along with the increased of economic status. The beneficiaries of microfinance of Syangja district have increased their access to education and healthcare centre after joining microfinance because of the improvement in economic condition. Traditional practice of borrowing money from landlord is broken and transferred to formal institution which also increases the confidence level of small holders. Basically, women empowerment is highly significant. Decision making capacity, exposure in different social activities, management skill, communication skill and leadership skill of women is empowered which significantly contributing in the change of social system. Gender discrimination is reduced and women are also coming in-front of development activities. There was significant difference between the poor and non-poor beneficiaries of microfinance in the changes of education, 
healthcare and economic empowerment of women whereas there was no difference in decision making and aware on the right of household assets.

\section{WORKS CITED}

Armendariz deA., B., \& Morduch, J. (2005). The economics of microfinance. USA: Massachusetts Institute of Technology.

Ashe, J., \& Parrott, L. (2001). Impact evaluation of PACT's Women's empowerment program in Nepal: A savings and literacy led alternative to financial institution building. Cambridge: Brandeis University.

Cheston, S., \& Kuhn, L. (2002). Empowering women through microfinance. New York: UNIFEM.

Department of Health Service. (2007). Annual report 2063/64. Kathmandu: Government of Nepal.

Kabeer, N. (2003). Assessing the 'Wider' social impacts of microfinance services: Concepts, methods, findings. IDS Bulletin , 34 (4), pp. 106- 114.

Krishna, A. (2003). Social capital, community driven development, and empowerment: A short note on concepts and operations. Washington, DC: World Bank.

Littleield, E., Murduch, J., \& Hashemi, S. (2003). Is microfinance an effective strategy to reach the millennium development goals. Focus Note (24)., CGAP.

Ministry of Health and Population. (2006). Guideline for free essential health care services for poor and destitute people. Kathmandu: Government of Nepal.

Nepal Government. (2007). The interim constitution of Nepal 2063. Kathmandu: Kanun Kitab Khana.

Noponen, H. ( 2005). The internal learning system - Assessing impact while addressing learning needs. Journal of International Development , (17), pp. 195-209.

Okibo, B. W., \& Makanga, N. (2014). Effects of micro finance institutions on poverty reduction in Kenya. International Journal of Current Research and Academic Review , 2 (2), pp. 76-95. 
120 IMPACT OF MICROFINANCE ON THE SOCIAL DEVELOPMENT OF ...

Robinson, M. (2001). The microfinance revolution: Sustainable finance for the poor. Washington DC: World Bank.

WHO. (2011). Health financing for universal coverage and social health protection: Bridging the health care divide . Technical Working Group on Health Care Financing. Kathmandu: World Health Organization, Nepal.

World Bank. (2001). Engendering development: Through gender equality in rights, resources, and voice. Washington DC: World Bank.

Wright, G. (2000). Microfinance systems. Designing quality financial services for the poor. London and New York: Zed Books Ltd.

Zohir, S., \& Matin, I. (2004). Wider impacts of MFIs: Issues and concepts. Journal of International Development, 16 (3), pp. 301-330. 